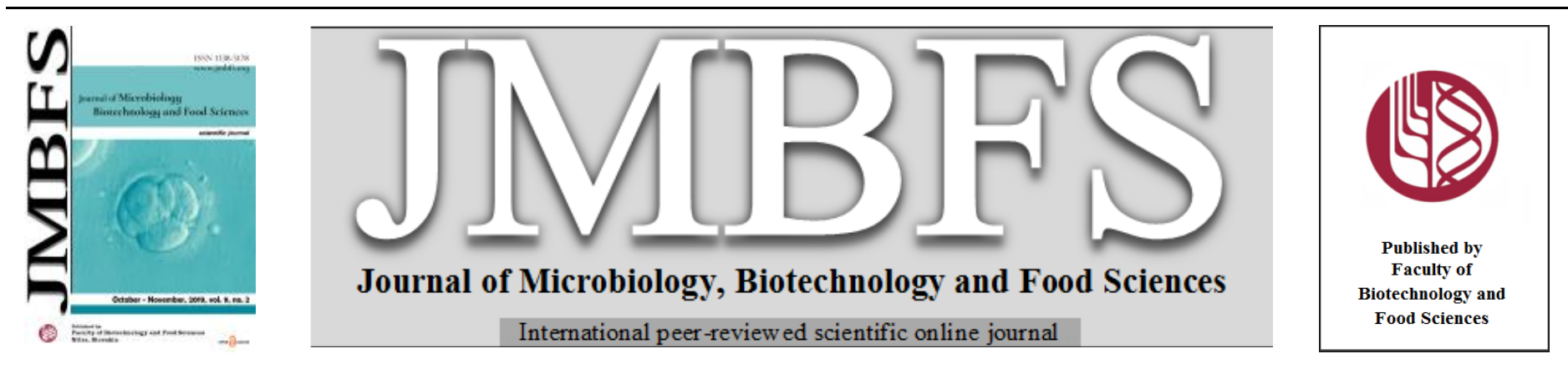

\title{
EFFECT OF CEDAR (CEDRUS LIBANI A. RICH) TAR ON BACTERIAL GROWTH
}

\author{
Hatice Aysun Mercimek Takci ${ }^{*}$, Filiz Ucan Turkmen ${ }^{2}$, Mehmet Sari $^{3}$ \\ Address(es): \\ ${ }^{1}$ Kilis 7 Aralık University, Faculty of Science and Letters, Molecular Biology and Genetics Department, 79000 Kilis, Turkey. \\ ${ }^{2}$ Kilis 7 Aralık University, Faculty of Engineering and Architecture, Food Engineering Department, 79000 Kilis, Turkey. \\ ${ }^{3}$ Mersin University, Faculty of Medicine, Basic Medical Sciences, Mersin, Turkey. \\ *Corresponding author: mersimek@hotmail.com
}

doi: 10.15414/jmbfs.2020.9.4.805-808

\section{ARTICLE INFO}

Received 20. 6. 2019

Revised 11. 9. 2019

Accepted 26. 9. 2019

Published 3. 2. 2020

\section{Regular article}

open 2 access

\begin{abstract}
The main objective of this study is to research the inhibitory effect of Cedar tar produced from cedarwoods collected from Gume village of Mut, Mersin, Turkey, against Escherichia coli and Staphylococcus haemolyticus using scanning electron microscopy. The inhibitory effect of cedar tar at varying concentrations (0.1-100\%) was examined on bacterial growth (E. coli and S. haemolyticus) by using KirbyBauer agar diffusion method. Cedar tar showed a strong inhibitory activity in the range of $15-30 \mathrm{~mm}$ against all tested microorganisms. The MICs value of Cedar tar was 5\% for E. coli and S. haemolyticus. The bacterial growth in liquid culture including 5\% Cedar tar was observed by optical density and standard plate count method for $24 \mathrm{~h}$. The optical density and viable cell counts in culture including Cedar $\operatorname{tar}(5 \%)$ reduced after $2 \mathrm{~h}$ of incubation period for all test strains. The bacterial colonies belonging to tested strains were not encountered on agar plates at the end of $10 \mathrm{~h}$ incubation. The cell images were not also determined in SEM micrographs of cultures with Cedar tar. Our data clearly indicated that cedar tar obtained by traditional thermal method had a strong inhibitory activity on bacterial cells.
\end{abstract}

Keywords: Bacterial growth, Cedar tar, Katran, MIC, SEM

\section{INTRODUCTION}

Wood obtained from forest trees, has been widely used in building of various constructions such as mausoleums, temples, churches, houses, furniture, dams, palaces and ships because of its availability, durableness, aesthetic qualities and bioactive material content since ancient times (Boydak, 2003; Bilgen et al., 2012; Sadiki et al., 2012). Some woody trees such as Juniperus sp., Pinus spp., Betula spp., Fagus spp., Picea spp. and Cedrus spp have been evaluated to produce secondary metabolites that treat human and domestic animal diseases in local community. The most important of these secondary metabolites has been known as tar (Ari et al., 2014). Especially, Pinus sylvestris L. (Scots pine) and Cedrus libani A. Rich (Lebanon or Taurus cedar) woods are widely employed to produce tar in southern Turkey (Kurt and Isık, 2012).

Tar having distinctive smoky smell and dark brown-black color is a complex mixture. It is traditionally used to help inhaling of asthma patients' especially in Marrakesh and prevent, cure and heal some human diseases such as eczema, dandruff and ulcers. There are also application areas in veterinary as repellent against insects and snakes, antiseptic for wounds and scratches, curative for intestinal parasite (Pekgozlu et al., 2017). This wood extract is referred to as katran in Turkey (Bilgen et al., 2012). Katran is traditionally obtained by pyrolysis methods that is thermal conversion of biomass into gas, liquid and char product in the absence of oxygen (Kurt and Isık, 2012; Pekgozlu et al., 2017). Katran is recently produced by modern laboratory conditions as well as conventional methods (Kurt and Isık, 2012; Ari et al., 2014). The quality based on the chemical composition of katran is affected by the age of the tree (Ari et al., 2014).

The main objective of this study is to investigate the inhibitory effect of Cedar tar (katran) obtained from Cedrus libani A. Rich by traditional method against Escherichia coli and Staphylococcus haemolyticus by using scanning electron microscopy. For antibacterial experiments, Escherichia coli and Staphylococcus haemolyticus strains were selected due to being agent of nosocomial infection.

\section{MATERIAL AND METHODS}

\section{Production of Cedar tar}

In this study, Taurus Cedar (Cedrus libani A. Rich) that grows commonly and naturally in Mediterranean region was used for Cedar tar production. Cedarwoods were collected from Gume village of Mut, Mersin, Turkey. The hole (ignition compartment) was dug in the ground depending upon the amount of wood. Two metal cans, one of them is lidless, were obtained. Dry cedarwood was cut into small pieces and the covered metal can was filled with these pieces. They were provided to connect each other by placing the collecting can (lidless metal can) in the hole and the other one onto collecting can. The burning process was started by igniting pieces and continued at high temperature (average $400^{\circ} \mathrm{C}$ ) for 1-2 $\mathrm{h}$ for a better tar yield. After then, Cedar tar was collected with distinctive smoky smell and dark brown-black color from collecting can.

\section{Minimal inhibitory concentration (MIC) of Cedar tar}

E. coli and S. haemolyticus clinical strains were donated from Kilis State Hospital, Kilis, Turkey. The concentration of Cedar tar obtained after burning process was accepted as $100 \%$. The inhibitory effect of cedar tar at varying concentrations $(0.1-100 \%)$ as well as the standard antibiotics (Vancomycin and Erythromycin) as positive control on bacterial growth was examined by using the agar diffusion method (Kirby-Bauer Method). The turbidity of the overnight bacterial culture was adjusted to $0.5 \mathrm{McFarland}$ standard reference range Following the inoculation on Mueller Hinton Agar, the plates were incubated at $37^{\circ} \mathrm{C}$ for $24 \mathrm{~h}$.

Standart discs $(6 \mathrm{~mm}$ in diameter) were embrued with $30 \mu \mathrm{L}$ of the cedar tar. Then the clear zones around the disc and well were evaluated as the inhibition zones and subsequently measured in $\mathrm{mm}$.

\section{Growth condition of strain in the culture including Cedar tar}

The bacterial strains were pre-incubated in nutrient broth at $37^{\circ} \mathrm{C}$ for $24 \mathrm{~h}$. The initiation optical density of cultures was adjusted to average 0.1 at $600 \mathrm{~nm} .5 \mathrm{~mL}$ of this suspension was dispensed into $500 \mathrm{~mL}$ sterile flask including $95 \mathrm{~mL}$ nutrient broth and 5\% final concentration of the Cedar tar. The flasks were 
incubated at $120 \mathrm{rpm}$ for $30^{\circ} \mathrm{C}$ and $24 \mathrm{~h}$. Bacterial growth in Nutrient broth including Cedar tar at concentration determined according to MIC results was followed by measuring the optical density at $600 \mathrm{~nm}$ and counting viable colonies on agar plates (Plate Count Agar). Bacterial culture without Cedar tar as control was prepared. \% reduction in bacterial cell count was determined according to initiation cell count. Experiments were performed in three times. And standard deviations were calculated by averages of cell counts in repetitions.

\section{Scanning electron microscopy analysis}

The samples were viewed by SEM without fixation protocol. The surface of the sample covering-stubs was coated by gold particle (Quorum Q150R Sputter Coater). The effect of Cedar tar on bacterial growth was viewed by using scanning electron microscopy (FEI Quanta FEG 650) at $10 \mathrm{kV}$ accelerating voltage.

\section{RESULTS AND DISCUSSION}

\section{MICs and Total Antibacterial Activity of Cedar Tar}

The antibacterial activity of Cedar tar against $E$. coli and $S$. haemolyticus strains is presented in Table 1 which clearly observes that Cedar tar has shown good antibacterial activity against E. coli and S. haemolyticus. Cedar tar at the $100 \%$ concentration showed better activity than the standard antibiotics against al tested bacteria. The inhibition zone of Vancomycin, the effective antibiotic against S. haemolyticus, was $20 \mathrm{~mm}$ whereas the antibacterial activity of Cedar tar was $30 \mathrm{~mm}$. Similarly, the inhibitory effect showed by Erythromycin standard antibiotic against $E$. coli was limited with $9 \mathrm{~mm}$. The activity of Cedar tar on $E$ .coli was $15 \mathrm{~mm}$. According to these results, Cedar tar was more effective agains S. haemolyticus.

The microbial sensitivity to the different concentration of Cedar tar represented by the mean MIC values. The MICs value of Cedar tar was $5 \%$ for $E$. coli and $S$ haemolyticus (Table 1). The rest of the low concentrations of Cedar tar ( 0.1 and $1 \%$ ) were ineffective on E. coli and S. haemolyticus. The antibacterial effect of Cedar tar at the 50 and $10 \%$ concentration was observed to preserve against all tested bacteria. The highest antibacterial activity of Cedar tar showed against $S$ haemolyticus with $23-15 \mathrm{~mm}$ zone diameters for 50 and $10 \%$ concentrations. The inhibition effect observed against $E$.coli at the same concentrations was 15 and $11 \mathrm{~mm}$. Based on these results, E. coli, the Gram-negative bacteria, were observed to be more resistance to Cedar tar than $S$. haemolyticus, the Grampositive bacteria.

\section{Table 1 MIC values of Cedar tar (in terms of mm)}

\begin{tabular}{ccc}
\hline \multirow{2}{*}{ Cedar tar concentrations $(\%)$} & \multicolumn{2}{c}{ Inhibition zone (mean diam, mm) } \\
\cline { 2 - 3 } & E. coli & S. haemolyticus \\
\hline 100 & 15 & 30 \\
50 & 15 & 23 \\
10 & 11 & 15 \\
5 & 7 & 7 \\
1 & $-*$ & $-*$ \\
0.1 & $-*$ & $-*$ \\
\hline
\end{tabular}

-*: Any inhibition zone was not observed on MHA plates.

The previous studies related to Cedrus libani A. Rich are limited to research the antimicrobial activity and chemical composition of extracts and oils of the leaves, stems, and pulp of Taurus Cedar. The antibacterial and antifungal properties of water and methanolic extracts of the leaves, stems, and pulp of Lebanese Cedar against Klebsiella pneumonia, MRSA, ESBL E. coli, Listeria monocytogenes and Candida albicans were reported in previous study (Ghanem and Olama, 2017). Hudson et al. (2011) declared that the antimicrobial activity of Cedar leaf oil to Bacillus subtilis, Streptococcus pyogenes, Enterococcus fecalis, Acinetobacter baumannii, Hemophilus influenzae, Salmonella enteritidis and Escherichia coli. In another study, antibiofilm and antihyphal activities of cedar leaf essential oil on C. albicans were searched (Manoharan et al., 2017).

Chaudhari et al. (2012) determined that cedarwood oil had antimicrobia activity against Streptococcus mutans. The bactericidal activity of Cedarwood essential oil on Staphylococcus aureus, Bacillus subtilis and Bacillus cereus was noted by Zrira and Ghanmi (2016).

The analysis of bacterial growth in the liquid media including Cedar tar was continued with $5 \%$ concentration of tar.

\section{Analysis of Bacterial Growth in the Presence of Cedar tar}

Time-dependent change in turbidity and viable bacterial counts (CFU mL $\left.\mathrm{mL}^{-1}\right)$ during $0,2,4,6,8,10,12$ and $24 \mathrm{~h}$ of incubation were followed. The initia inoculum values for $0.1_{\mathrm{OD}(600)}$ was about 30 and $35 \times 10^{6} \mathrm{CFU} \mathrm{mL}^{-1}$ for all strains The bacterial count in the control culture during growth was observed the difference form phase to phase.

The viable colony counts for $E$. coli arose after $2 \mathrm{~h}$ incubation period $\left(46 \pm 2.85 \times 10^{6} \mathrm{CFU} \mathrm{mL}^{-1}\right)$ and followed logarithmic increasing then reached to maximum cell counts at $10 \mathrm{~h}$ of incubation in control culture. Viable bacterial count was $115 \pm 1.65 \times 10^{6} \mathrm{CFU} \mathrm{mL}^{-1}$ for 0.331 optical density at the end of the 10 $\mathrm{h}$ incubation (Fig 1).

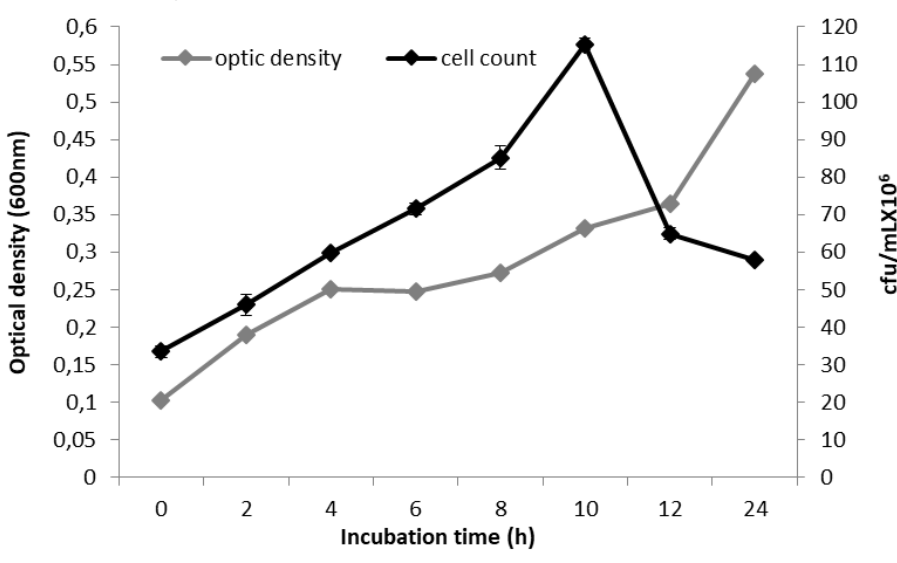

Figure 1 Viable cell count and optical density as measures of growth in E. coli control culture

The number of CFU per millimeter increased during the period of $10 \mathrm{~h}$ incubation after then decreased. However, the optical density ratio (OD 600) from each point time was continued to increase. The growth curve of culture including Cedar tar was indicated to the time-dependent decrease (Fig 2). Following $2 \mathrm{~h}$ incubation with Cedar tar, the rate of cell viability was $63 \%$ $88.24 \%$ reduction in $E$. coli cell count was detected at the end of $8 \mathrm{~h}$ compared to control. And bacterial colony belonging to E. coli was not observed on PCA at 10 $\mathrm{h}$ and the rest of incubation period. Viable colony counts in the control and test culture at the end of $8 \mathrm{~h}$ were $85 \pm 3.05$ and $10 \pm 0.50 \mathrm{CFU} \mathrm{mL} \mathrm{m}^{-1}$, respectively. The optical density for $E$. coli culture with tar remained nearly constant according to the initiation inoculum value.

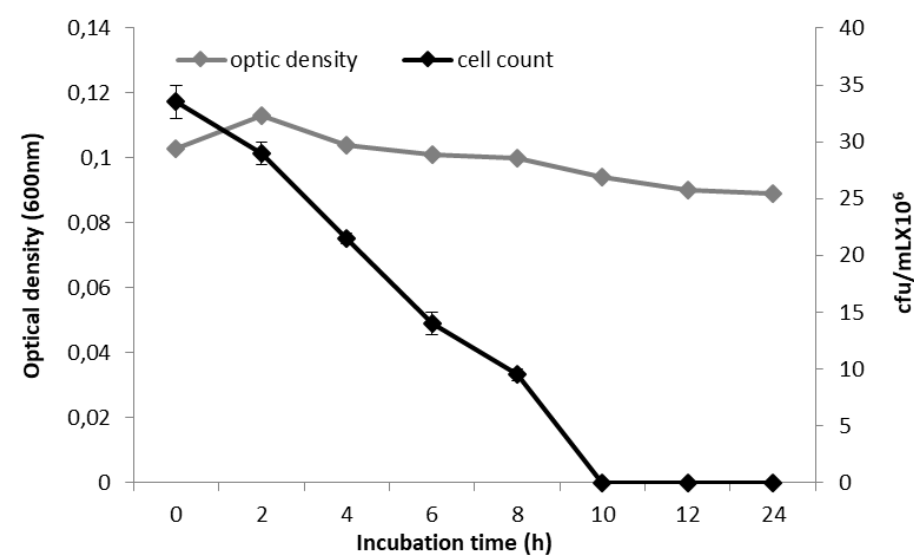

Figure 2 Viable cell count and optical density as measures of growth in E. coli culture with $5 \%$ Cedar tar

The similar results were also obtained for S. haemolyticus control and test culture. A logarithmic increase in the optical density of control culture was observed at the end of $24 \mathrm{~h}$ incubation (Fig 3). The maximum optical density measured at this period was $0.469 \mathrm{OD}(600)$. The colony count for control culture reached with $83 \times 10^{6} \pm 1.00 \mathrm{CFU} \mathrm{mL} \mathrm{m}^{-1}$ after approximately $8 \mathrm{~h}$ (Fig. 4).

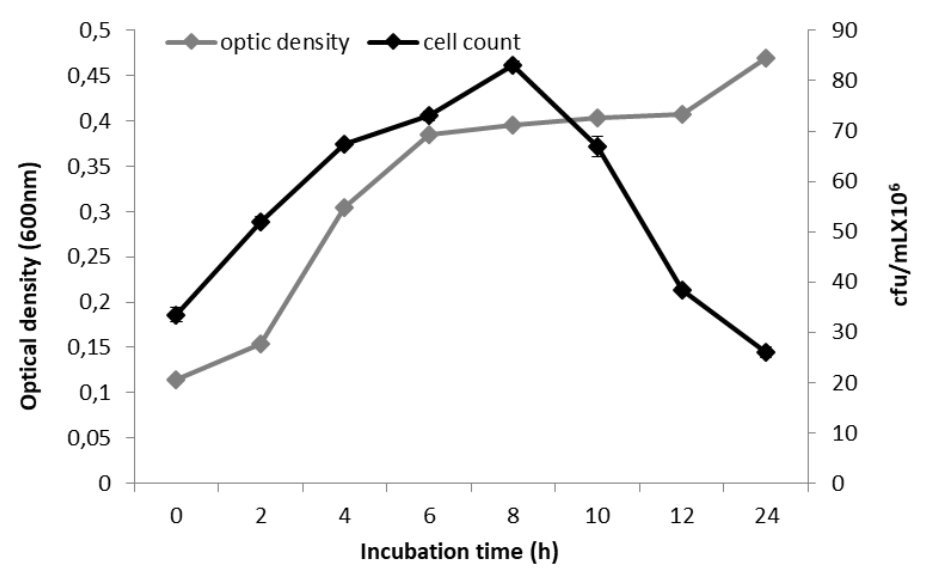

Figure 3 Viable cell count and optical density as measures of growth in $S$. haemolyticus control culture 
However, the total cell count based on optical density in bacterial culture including Cedar tar decreased to 0.101 oD(600) only after 2 h. $49 \%$ decrease in viable cell count for this period was also observed. Following incubation the viable cell count was $14 \times 10^{6} \pm 1.50 \mathrm{CFU} \mathrm{mL} \mathrm{mL}^{-1}$ reduced by $83.13 \%$ at the end of 8 $\mathrm{h}$ according to control (Fig 4). The viable colony was not observed on PCA for the residue incubation time.

The accumulation of metabolic waste products and the decrease of nutrition substances as increased bacteria growth may be caused the time-depend reduction of viable cell count in the control culture. The turbidity of cultures may be increased depending metabolic waste products, dead and divided cells in spite of reducing in cell count

SEM images obtained after incubating for $10 \mathrm{~h}$ are given Figure 5 and 6 . The sphere-shapes cell images were viewed in size between $0.85-1.23 \mu \mathrm{m}$ for samples taken from $S$. haemolyticus control culture. The rod-shapes cells belonging to $E$. coli in size $0.70-1.20 \mu \mathrm{m}$ were observed on SEM images. However, the microscopic images of bacteria cells were not encountered in the micrographs of test cultures containing Cedar tar. The results of SEM analysis are supported our findings on inhibitory activity of Cedar tar against all the tested bacteria.

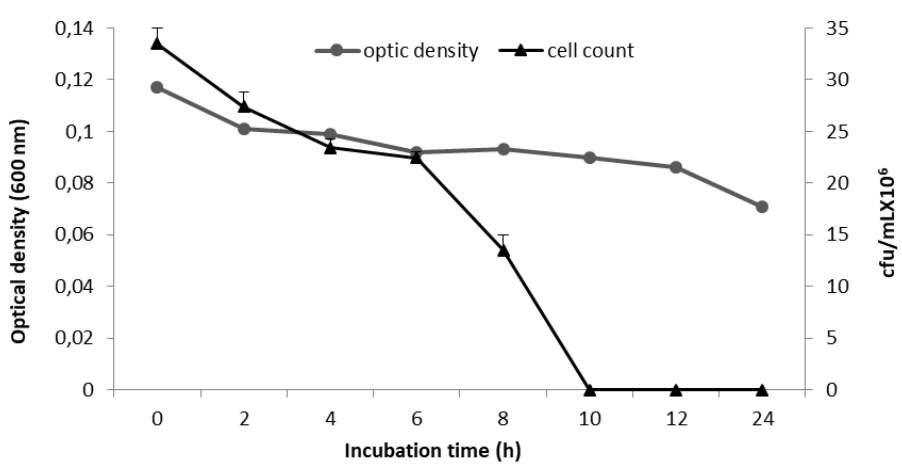

Figure 4 Viable cell count and optical density as measures of growth in $S$ haemolyticus culture with $5 \%$ Cedar tar
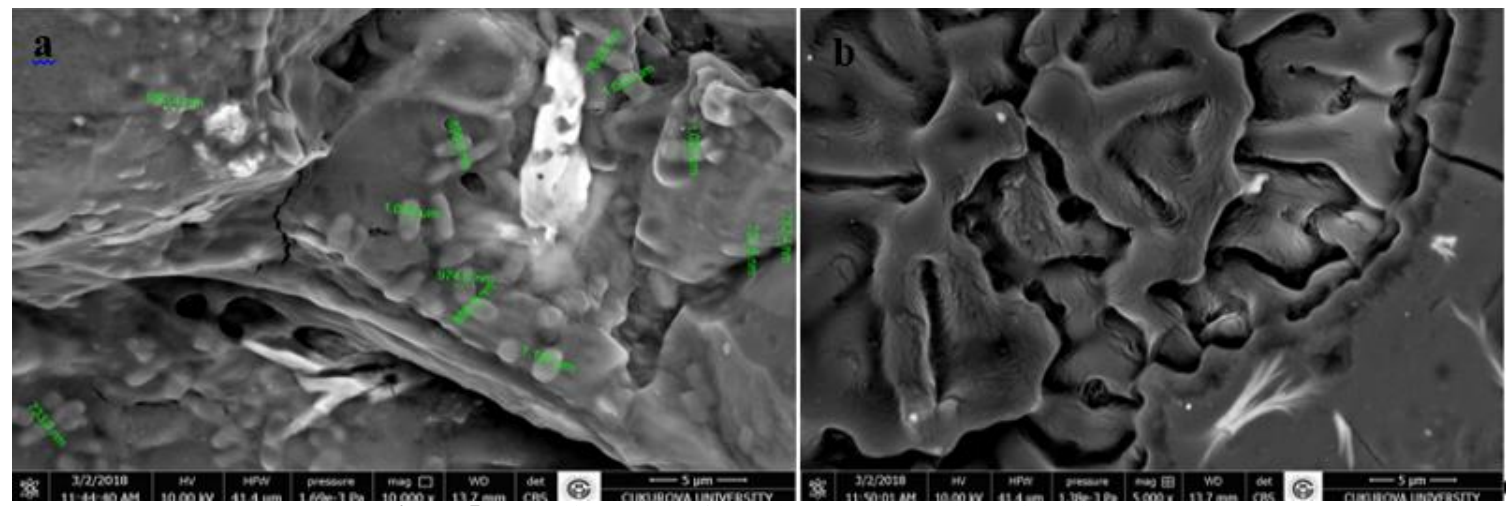

Figure 5 SEM micrograph of $E$. coli control (a) and test (b) cultures
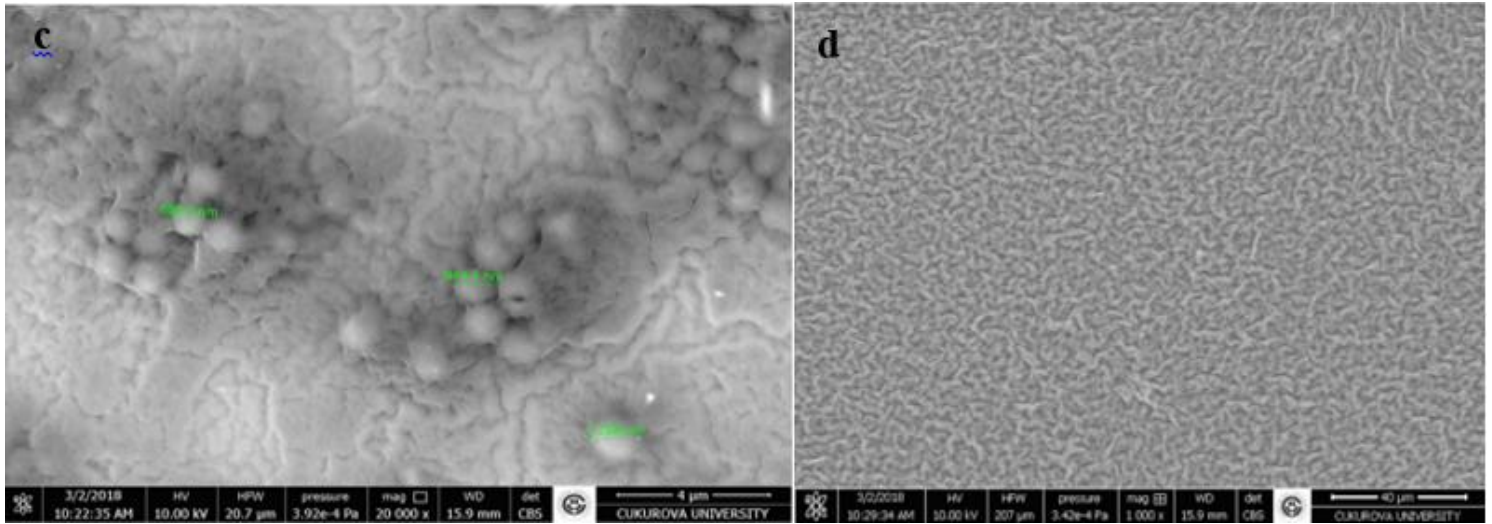

Figure 6 SEM micrograph of S. haemolyticus control (c) and test (d) cultures

After incubating for $8 \mathrm{~h}, \%$ reduction in $S$. haemolyticus and $E$. coli culture was calculated as 83.13 and $88.24 \%$, respectively. The variation in the sensitivity observed against Cedar tar between E. coli and S. haemolyticus may be clarified by the difference of their cell wall structure. The Gram-negative bacteria have thin peptidoglycan cell wall as against Gram-positive bacteria. While the cell wall of the Gram positive bacteria consists of $80-90 \%$ layers of peptidoglycans, this rate for the Gram negative bacteria is $10 \%$ due to being the outer membrane. The thickness of cell wall prevents and retards the passing of the antibacterial agents to the cytoplasmic membrane. So, this structure causes the resistance capability against antimicrobial agents of bacteria. This is explained why $S$. haemolyticus having thick peptidoglycan cell wall was relatively resistance against Cedar tar compared to $E$. coli. But Cedar tar was more effective against $S$. haemolyticus on agar than E. coli. This is not a contradiction. Because the reproduction behavior of bacteria are different from solid to liquid medium based on content of media and culture density.

In brief, the inhibitory effect of Cedar tar on tested strains was investigated depending upon the time-dependent. Our results revealed that Cedar tar was effectively inhibited $E$. coli and S. haemolyticus growth. This powerful effect may be associated with the secondary bioactive metabolites such as $\beta$ himachalane, $\alpha$-himachalane and longifolene released by temperature treatment $\beta$-himachalane (22-28\%) is a sesquiterpene. It is the most abundant compound in all tars, especially in the branches. It is reported to the antifungal and insecticidal activity of $\beta$-himachalane and its derivates from cedarwood. The other important bioactive compounds are defined as $\alpha$-himachalane (6-10\%) and longifolene (79\%) (Daoubi et al., 2005; Derwich et al., 2010; Pekgozlu et al., 2017).
According to these result, the traditional usage of Cedar tar in the control of bacteria responsible for human and domestic animal infections can be an alternative to standard antimicrobial agents such as antibiotics. But the antibacterial mechanism of Cedar tar has not been understood yet. So, the safety and acceptability of Cedar tar for treatment of various infections should be determined by using in vivo test system.

\section{CONCLUSION}

In this study, we emphasized to the traditional tar production process applied by local people and the antibacterial effectiveness of Cedar tar against Escherichia coli and Staphylococcus haemolyticus strains. To our knowledge, no work has been previously published on investigation of the inhibitory effect of Cedar tar by using SEM analysis. More specific studies are needed to examine the isolation and characterization of bioactive constituents in Cedar tar for developing new antibacterial drugs.

Acknowledgements: This present study was presented at III. International Vocational and Technical Sciences Congress (UMTEB'18), Gaziantep, Turkey and published as abstract. The authors would like to thank Kilis 7 Aralık University for laboratory opportunity and Cukurova University Central Research Laboratory, for using SEM. 


\section{REFERENCES}

Ari, S., Kargioglu, M., Temel, M. \& Konuk, M. (2014). Traditional Tar Production from the AnatolianBlack Pine [Pinus nigra Arn. subsp. Pallasiana (Lamb.) Holmboe var. pallasiana] and its usages in Afyonkarahisar, Central Western Turkey. Journal of Ethnobiology and Ethnomedicine, 10(29), 1-9. https://doi.org/10.1186/1746-4269-10-29.

Bilgen, B. B., Kurt, Y. \& Kaya, N. (2012). Mating system in natural populations of Taurus cedar (Cedrus libani A.Rich.). Turkish Journal of Agriculture Foresty, 36, 379-387. https://doi.org/10.3906/tar-1104-29.

Boydak, M. (2003). Regeneration of Lebanon cedar (Cedrus libani A. Rich.) on karstic lands in Turkey. Forest Ecology Management, 178, 231-243. https://doi.org/10.1016/S0378-1127(02)00539-X.

Chaudhari, L. K. D., Jawale, B. A., Sharma, S., Sharma, H., Kumar, C. D. M. \& Kulkarni, P. K. (2012). Antimicrobial Activity of Commercially Available Essential Oils against Streptococcus mutans. Journal of Contemporary Dental Practice, 13(1), 71-74. https://doi.org /10.5005/jp-journals-10024-1098.

Daoubi, M., Hernaandez-Galaa, R., Benharref, A. \& Collado, I. G. (2005). Screening Study of Lead Compounds for Natural Product-Based Fungicides: Antifungal Activity and Biotransformation of 6r,7r-Dihydroxy- $\hat{a}$-himachalene by Botrytis cinerea. Journal of Agricultural and Food Chemistry, 53, 6673-6677. https://doi.org/10.1021/jf050697d.

Derwich, E., Benzianei, Z. \& Boukir, A. (2010). Chemical composition and In vitro antibacterial activity of the essential oil of Cedrus atlantica. International Journal of Agriculture and Biology, 12, 381-385.

Ghanem, S. \& Olama, Z. (2014). Antimicrobial Potential of Lebanese Cedar Extract against Human Pathogens and Food Spoilage Microorganisms. European Journal of Botany, Plant Science and Phytology, 1(1), 13-26.

Hudson, J., Kuo, M. a \& Vimalanathan, S. (2011). The Antimicrobial Properties of Cedar Leaf (Thuja plicata) Oil; A Safe and Efficient Decontamination Agent for Buildings. International Journal of Environmental Research and Public Health, 8, 4477-4487. https://doi.org10.3390/ijerph8124477

Kurt, Y. \& Isik, K. (2012). Comparison of Tar Produced by Traditional and $\begin{array}{llll}\text { Laboratory } & \text { Methods. } & \text { Ethno-Medicine, } & 6(2),\end{array}$ https://doi.org/10.1080/09735070.2012.11886423.

Manoharan, R. K., Lee, J-H. \& Lee, J. (2017). Antibiofilm and Antihyphal Activities of Cedar Leaf Essential Oil, Camphor, and Fenchone Derivatives against Candida albicans. Frontiers in Microbiology, 8, 1-12. https://doi.org/10.3389/fmicb.2017.01476.

Pekgozlu, A. K., Kustas, S., Mercan, B. \& Bicer, A. (2017). Chemical Characterization of Lebonan Cedar Tar. Drvna Industrija, 68(2), 107-112. https://doi.org/10.5552/drind.2017.1607.

Sadiki, M., El Abed, S., Balouiri, M., Barkai, H., El Bergadi, F.Z., El Farrıcha, O. \& Ibnsouda Koraich, S. (2017). Combined effect of essential oils against bacteria associated with deterioration of historical wood. Journal of materials and Environmental Sciences. 8(2), 594-602.

Zrira, S. \& Ghanmi, M. 2016. Chemical Composition and Antibacterial Activity of the Essential of Cedrus atlantica (Cedarwood oil). Journal of Essential Oil $\begin{array}{llr}\text { Bearing Plants,. } & 19(5), & 1267-1272 .\end{array}$ https://doi.org/10.1080/0972060X.2015.1137499. 